Agro-Science Journal of Tropical Agriculture, Food, Environment and Extension Volume 19 Number 3 (July 2020) pp. 1 - 7

ISSN 1119-7455

\title{
GENDER PARTICIPATION IN NON-FARM EMPLOYMENT IN EBONYI STATE, NIGERIA
}

\author{
*Onya S.C., Amah-Jerry E.P. and Iheke O.R. \\ Department of Agricultural Economics, \\ Michael Okpara University of Agriculture, Umudike, Abia State, Nigeria \\ *Corresponding author's email: simeononya@yahoo.com
}

\begin{abstract}
This study examined gender participation in non-farm employment in Ebonyi State, Nigeria. The study used primary data collected from 149 respondents selected through a multistage sampling technique. Data were analysed using descriptive statistics and double hurdle model. The result of the descriptive statistics showed that female household heads were younger (38.3 years) than the male (44.4 years), the male had more years of education, spent more time in work than the female; and also the male farm income were more than that of the female, while the female non-labour income were higher than that of the male. Also, the females were more involved in tree cropping and livestock-keeping than their male counterparts, while on the non-farm activities, the female were more into these practices than the male. The result of the double hurdle estimation showed that age, marital status, years spent in school, household size, number of dependent, farm size, non-labour income, and distance to the market significantly influenced the participation decision of both male and female headed households in non-farm employment; while age, marital status, years spent in school, household size, number of dependent, farm size, non-labour income, distance to the market, and distance to the urban centre significantly influenced the hours of work decision of male and female headed households in non-farm employment in the study area. The study recommends policy measures that will improve the skills and educational level of the farmers especially the female as it will go a long way in reducing the number of unskilled labours while increasing the number of skilled labour of the people in the study area.
\end{abstract}

Key words: gender, participation decision, hours of work decision, non-farm employment

\section{INTRODUCTION}

Gender differential in labour, wage, land distribution and productivity are critical issues that have been central to the socio-economic life of countries in Africa. In Nigeria, women constitute half or more of the country's population, but they contribute lesser than men towards the value of recorded production both quantitatively in labour force participation and qualitatively in educational achievement and skilled manpower (Olukemi, 2009). Available evidence portrayed rural non-farm employment as a continuously occurring phenomenon of adding onto on-farm employment, new forms of non-farm livelihood activities, and thereby expanding available livelihood options for both men and women (Davis and Bezemer, 2004).

In agricultural societies, considerable gender disparities in access to non-farm employment opportunities usually exist. Nicodemo and Waldmann (2009) reported that both employment and participation are influenced by supply and demand factors. On the supply side, gender specialization in both farm production and household activities dictate gender differences in both time constraints and the value of time. On the demand side, qualifications such as formal education dictate differences between the demand for male labour and the demand for female labour. Both supply and demand could also be subject to considerable gender discrimination in traditional societies in which most of these factors work against women. However, increasing women's position is known to be favourable not only to household income but also to child education, health and nutritional status of all household members (Quisumbing, 2003). More so, labour market opportunities are an important determinant of women's bargaining power in household decision making, which has been shown to be positively correlated with household spending on goods that benefit children, (Costa and Bob, 2012).

Right from the pre- colonial traditional Nigeria society to its modern state, women have often been discriminated upon in affairs that led to deplete their contribution to aggregate employment. Such discrimination is often perceived in grounds that they are the weaker sex. Women rarely own land, may have lower education due to discriminatory access as children, and their access to productive resources as well as decision-making tend to occur through the mediation of men (Oluwatayo, 2009). 
The fact that women and men particularly in Africa have significantly different roles in the making of livelihoods decisions, calls for the need to further understand how gender influence individual decision to participate in non-farm employment. (Simtowe, 2010). It is possible for participation in non-farm employment to improve the independent income generating capabilities of women, care and nutritional status of children. This is because a high proportion of cash income in the hands of women tends to be spent on family welfare (Simtowe, 2010).

Rural livelihood portfolio is widely known to be expanding and diversifying beyond agriculture (Csaki and Lerman, 2000; Davis and Bezemer, 2004; Idowu et al., 2013). However, very little is known on gender dimension of rural non-farm employment and whether gender makes any difference in rural dwellers choices of livelihood. Hence the objectives of the study were to (i) examine the socioeconomic characteristics of the respondents, (ii) identify major types of non-farm employment available, and (iii) estimate the determinants of participation in nonfarm employment in the study area.

\section{MATERIALS AND METHODS}

The study was carried out in Ebonyi State, Nigeria. The state is located in the Southeastern Nigeria, and lies within latitude $5.40^{\prime}$ and $6.45^{\prime} \mathrm{N}$ and longitude $7.30^{\prime}$ and 8.30'E. It covers an area of $6,421.2 \mathrm{~km}^{2}$ with a population of $2,176,947$ (NPC, 2006) which accounts for $1.6 \%$ of total Nigeria population. The state is characterised by mean annual rainfall of between $2250 \mathrm{~mm}$ in the south and $1500 \mathrm{~mm}$ in the North with an average temperature of about $27^{\circ} \mathrm{C}$ and relative humidity of $85 \%$. The people are predominantly farmers and grow crops such as rice, yam, maize, oil palm and vegetables; and they also rear livestock. Non-farm employment activities common in the area range from hired farm labourers, petty trading to civil service (Onya et al., 2016).

\section{Sampling Procedure}

Multi-stage sampling technique was adopted for the study. Ebonyi State is divided into three agricultural zones. The three agricultural zones were used for the study. The first stage involved the random selection of one local government area (LGA) from each agricultural zone where farming activities are predominant, namely Ohaukwu, Ikwo and Onicha LGAs. The second stage involved the random selection of two rural autonomous communities from each LGA namely Ezzamgbo and Ndi-Akpu in Ohaukwu LGA, Ndi-Achara and Eka Awoke in Ikwo LGA and Isu-Agueke and Abaomege in Onicha LGA making a total of six autonomous communities. Third stage involved the random selection of three villages from each of the selected autonomous communities making a total of 18 villages. The villages are Amechi, Amike, Amovu Ezzamgbo in Ezzamgbo Autonomous Community,
Ndiagu, Ogbodo, Nsulakpa in Ndi-Akpu Autonomous Community, Agubata-Ndufu, Ndiagu, Umoka Ndiufu in Ndi-Achara Autonomous Community, Aguiyima Echare-Ukwu Ezeke in EkaAwoke Autonomous Community, Obeagu, MbalaUkwu, Agba in Isu-Agueke Autonomous Community and Ebusirike, Omege, Okworike in Abaomege Autonomous Community. In the final stage, random selection of 10 farming households from the 18 selected villages gave a sample size of 180 rural households (of both male and female headed households) used for the study. Out of the 180 questionnaires distributed to the farmers 149 consisting of 96 male headed households and 53 female headed households were found useful for the study and consequently used for the study.

\section{Data Analysis \\ Descriptive statistics such as frequency counts, percentages and means were used to present the results for the first and second objectives, while the double hurdle modelling approach was used to analyze for the third objective.}

\section{Specification of Non-Farm Labour Supply Function}

Many empirical studies analyzed non-farm labour supply of farm households by considering a binary choice dependent variable (participation versus nonparticipation), and thus estimated a Probit model (Beyene, 2008; McCarthy and Sun, 2009) or a logit model (Norsida and Ismaila, 2009; Roslan and Siti, 2011; Onya et al., 2016). But both models ignore an important aspect of labour supply decision, i.e, the hours of work decision. As a solution to this problem, some other studies examined the non-farm labour supply decision of households using single equation Tobit model (Tassew, 2000; Abebe, 2002).

However, the Tobit model by itself has many drawbacks. In the Tobit specification, first, all zero observed hours of work are interpreted as corner solutions. Second, it is based on a restrictive assumption that both participation and the hours of work decision given the decision to participate are determined by the same set of variables which implies that a variable that increases the probability of participation also increases the number of hours worked (Wooldridge, 2002). Thus, as an alternative approach, the non-farm labour supply of male and female members of households could be modeled as a two-stage (double hurdle) process. This method provides a general approach to modelling participation and hours of work decision as two stage decision process. Although the approach was widely used in the empirical studies of consumer demand and agricultural technology adoption (Simtowe and Zeller, 2007; Getachew et al., 2009; Onya et al., 2019), it has also been used to study labour supply decisions (Matshe and Young, 2004; Bedemo et al., 2013a). 
Therefore, it has the advantage that it permits the joint modeling of the decision to participate and the intensity of participation (hours of work) in the Non-farm labour market (Matshe and Young, 2004; Bedemo et al., 2013a). In this model, individuals should pass two-step decision processes; first they have to decide to participate in non-farm activity and then they need to work a certain hour in the labour market at a prevailing market wage. Therefore, if we observe a positive hour of work, the inference is that the individual concerned has completed a two-stage process. In other words, the zero hours of work observed is because of the participation decision (not participating) or the hours of work decision (not supplying positive hours of work) or both.

The model works under the assumption that there exist two latent variables which are $\gamma_{1}^{* *}$ related with the individual's decision to participate in the non-farm employment activity and $\gamma_{2}^{* *}$ with his decision on the number of hours worked in non-farm employment activity (Matshe and Young, 2004; Bedemo et al., 2013a). These latent variables are expressed as linear functions of the first and second hurdle regressors, $X_{1}$ and $X_{2}$, respectively:

$$
\begin{aligned}
& \gamma_{1}^{* *}=\chi_{1 \beta_{1}}+\mu \\
& \gamma_{2}^{* *}=\chi_{2 \beta_{2}}+.
\end{aligned}
$$

where $X_{1}$ represents the regressors used to explain the participation decision in equation 1 and $X_{2}$ those used to explain the hours of work decision in equation 2. Suppose that an index variable $\gamma_{1}^{*}$ is expressed as $\gamma_{1}^{*}=1$ if the individual participates and $\gamma_{1}^{*}=0$, otherwise, then we have: $\gamma_{1}^{*}=1$ if $\gamma_{1}^{* *}>0$ $\gamma_{1}^{*}=0$, if otherwise.

Assuming that the error term $\mu_{1}$ in equation 7 is normally distributed, the first hurdle corresponds to a probit model. Similarly, turning to the hours of work equation, provided that the first hurdle was cleared, $\gamma_{2}^{*}$ can also be generated as:

$\gamma_{2}^{*}=\gamma_{2}^{* *}$, if $\gamma_{2}^{* *}>0$, and $\gamma_{2}^{* *}=0$, ifotherwise

This second hurdle takes the form of truncated regression and is capable of generating zero levels of non-farm labour hours, independent of the first hurdle. Finally, the observed (actual) hours of work, $\gamma$, is determined by the interaction of both hurdles, that is: $\gamma=\gamma_{1}^{*} \gamma_{2}^{2}$ The double-hurdle model specification assumes a bivariate normal distribution $(\mathrm{BVN})$ of latent variables given as:

$$
\left(\frac{\overline{\mu_{l}}}{v}\right) \sim B V N\left[0,\left(\begin{array}{cc}
\sigma_{\mu}^{2} & \rho \sigma_{\mu} \\
\rho \sigma_{\mu} & 1
\end{array}\right)\right]
$$

As indicated by Blaylock and Blissard (1992), this general model nests a number of formulations and extensions based on the assumptions made about $\rho$. For instance, if $\rho=1$, the model will be reduced to a standard Tobit model; and it will be an independent double hurdle or Cragg (1971) model if $\rho=0$. The use of maximum likelihood method to obtain consistent estimates in this approach is based on normality assumption. However, if this assumption is violated, the maximum likelihood estimates of the model will be inconsistent (Pagan and Vella, 1989). Thus, it is necessary to conduct test of normality besides covariance and Tobit restriction tests.

Variables; age (years), marital status (married = 1 , otherwise $=0$ ), household size (number), number of dependent (numbers), level of education (number of years spent in school), farm size (hectares), distance to the market $(\mathrm{km})$, farm income (naira), non-labour income (income from rent, remittances and pension), distance to the urban centre $(\mathrm{km})$.

\section{RESULTS AND DISCUSSION \\ Summary Statistics of the Socioeconomic Characteristics of Farmers in the Study Area}

Table 1 shows the summary statistics of the of the socioeconomic characteristics of the respondents. The average ages of the male and female headed households were 44.4 and 38.3 years respectively. Implying that the male headed household were older that the female headed households and that the respondents are relatively young and can actively participate in non-farm activities.

The mean household size of the respondents was 7 and 4 persons with standard deviation of 3.2 and 2.5 for the male and female headed households respectively. The mean years spent in school of the respondents were 9.1 and 8.6 years with standard deviation of 5.6 and 5.8 for the male and female headed households respectively. The average number of dependents of the respondents was 3.7 and 4.4 persons with mean deviation of 1.5 and 3.1 for the male and female headed households respectively. This implies that the male headed household head were more educated with large family size and less dependents than the female headed household heads.

The mean farm size of the respondents were 1.8 and 0.6 hectares with mean deviation of 1.0 and 0.6 for the male and female headed household respectively, implying that male headed household had larger farm size than the female headed household. This could be as a result of poor access to arable land by the female and also because of the need of the male to fend for his household as the overall head of the household.

The average non-labour income (income from rent, remittances and pension) of the respondents was $\$ 6208.33$ and $\$ 9849.06$ with mean deviation of 17573.3 and 20499.9 for male and female headed household, respectively. The higher non-labour income of the female headed households could be because most of the remittances sent by migrant wards are sometimes given to their mother believed to be weak and to need more care than the males. 
Table 1: Socio-economic characteristics of the respondents in the study area

\begin{tabular}{|c|c|c|c|c|c|c|}
\hline Variables & & Mean & Mean deviation & & Mean & Mean deviation \\
\hline Age & & 44.43 & 9.688 & & 38.26 & 7.25 \\
\hline Household size & & 6.34 & 3.21 & & 4.39 & 2.47 \\
\hline Years spent in school & & 9.05 & 5.58 & & 8.64 & 5.79 \\
\hline Number of dependants & & 3.65 & 1.48 & & 4.39 & 3.10 \\
\hline Farm size & $\stackrel{0}{=}$ & 1.79 & 0.95 & $\frac{0}{\pi}$ & 0.58 & 0.65 \\
\hline Non-labour income & $\stackrel{\pi}{\Sigma}$ & 6208.33 & 17573.3 & ฮี & 9849.06 & 20499.9 \\
\hline Farm income & & $145,031.3$ & 193077.3 & II & $72,301.89$ & 89521.29 \\
\hline Hours spent in work & & 4.92 & 3.49 & & 3.24 & 2.95 \\
\hline Distance to market & & 2.90 & 1.01 & & 2.92 & 1.69 \\
\hline Distance to urban centre & & 9.56 & 9.48 & & 11.58 & 9.88 \\
\hline
\end{tabular}

Distance to urban centre
Source: Field Survey, 2016

The mean farm income of the respondents was $\$ 145031.3$ and $\$ 72301.9$ per annum with mean deviation of 193077.3 and 89521.3 for the male and female headed households, respectively. This is in line with apriori expectation, since the male are more energetic and had larger farm size than the female. Hence the higher the farm size the higher the income derived from it. This corroborates the findings of Ahmadu and Idisi (2014) that women have less access to arable land than men in Nigeria.

The average distance to the market of the respondents was 2.9 and $2.9 \mathrm{~km}$ with mean deviation of 1.0 and 1.7 for the male and female headed households, respectively. The relatively close distance to the market of male and female headed households were because they virtually stay in the place and visit the same market irrespective of gender. The mean distance to the urban centre of the respondents was 9.6 and $11.4 \mathrm{~km}$ with mean deviation of 9.5 and 9.9 for the male and female headed households, respectively. The lower distance to the urban centre of the male could be as a result of the fact that male tend to go closer to the urban centre where they can easily find something to engage themselves with in order to be able to carter for the family they left behind.

The hours spent in work of the respondents were 4.9 and 3.2 hours with mean deviation of 3.5 and 3.0 for the male and female headed households, respectively. The lower hours spent in work by the female headed households relative to the male headed households is as a result of the fact that female headed households have responsibilities such as cooking and caring for their family unlike the male counterpart whose responsibility is to provide for his family and as such will tend to spend more time in work in order to make more income. This in line with the findings of (Bedemo et al., 2013b) who found that male spent more time at work than female that participated in non-farm employment.
Type and Sources of Non-Farm Employment The type of economic activities engaged by the farmers (both male and female-headed households) and their percentage distribution is presented in Table 2. From the result, all the farmers participated in arable cropping. Also, 22.9 and $26.4 \%$ of the male and female headed households, respectively engage in tree cropping; $33.3 \%$ and $43.4 \%$ of the male and female headed households, respectively engage in keeping of livestock in the study area. Then, $11.5 \%$ and $3.8 \%$ of the male and female headed households, respectively engaged in fishing. Fishing activity in the study area was, therefore, predominated by male. The male headed households dominated the forest activities having $8.3 \%$ while the female had $5.7 \%$.

For the non-farm activities, $53.1 \%$ and $62.3 \%$ of the male and female farmers were involved in nonfarm unskilled labour respectively. This shows that non-farm unskilled labour is dominated by female in the study area. $19.8 \%$ of the male headed households where engaged in non-farm skilled labour while $20.8 \%$ of the female headed households were involved in non-farm skilled labour. Non-farm selfemployment where dominated by male $(27.1 \%)$ relative to the female $(17.1 \%)$.

\section{Gender Participation in Non-Farm Employment (Double Hurdle Estimation Result): Participation Decision}

Gender participation in non-farm employment is presented in Table 3. The coefficient of age was positive and significant at $5 \%$ for male and female headed households respectively. This implies that age is directly related to participation decision of households in non-farm employment, i.e., as age increases the likelihood to participate in non-farm employment increases. This finding is contrary to Roslan and Siti (2011) and Ike (2015) who separately noted that the older the farmer, the less the probability for him/her to participate in non-farm employment.

Table 2: Distribution of the farmers according to type and sources of non-farm employment

\begin{tabular}{|c|c|c|c|c|c|c|}
\hline Type of activity & & Frequency & Percentage & & Frequency & Percentage \\
\hline \multicolumn{7}{|l|}{ Farm activities } \\
\hline Arable cropping & & 96 & 100 & & 53 & 100 \\
\hline Tree cropping & & 22 & 22.91 & & 14 & 26.41 \\
\hline Livestock production & & 32 & 33.33 & & 23 & 43.39 \\
\hline Fishing & $\frac{0}{\pi}$ & 11 & 11.45 & $\stackrel{\mathscr{Z}}{\mathbb{Z}}$ & 02 & 3.77 \\
\hline Forest related activities & $\sum^{\pi}$ & 08 & 8.33 & ] & 03 & 5.66 \\
\hline \multicolumn{7}{|l|}{ Non-farm activities } \\
\hline Non-farm unskilled labour & & 51 & 53.12 & & 33 & 62.26 \\
\hline Non-farm skilled labour & & 19 & 19.79 & & 11 & 20.75 \\
\hline Non-farm self-employment & & 26 & 27.08 & & 09 & 16.98 \\
\hline
\end{tabular}

Source: Field Survey, 2016 
The coefficient of marital status of male headed households was positive and significant at $10 \%$ while that of the female headed households was negative but not significant. The implication is that marital responsibility leads the household head into non-farm activities in order to argument their farm income.

The coefficient of years spent in school was positive and significant at 5 and $10 \%$ for male and female headed households respectively. This implies that participation decision of household increases as the level of education of the household head increases. Educated people are likely to diversify their income source relative to the non-literate and as such participation decision is high for the educated household heads. In other words, households with better educated head and with more number of educated members show a higher tendency to participate in labour markets as compared to non-literate ones. This is in line with some previous empirical studies (Zhang et al., 2003; Bedemo et al., 2013b; Ike, 2015) who noted that the more educated a farmer is, the more the likelihood that he or she will look for additional source of income outside farming. Furthermore, households with more number of educated family members choose working outside the farm. This may be supported by the fact that an increased education leads to an increased participation in non-farm employment as a result of which farmers tend to substitute farming for off-farm activities as long as the marginal of non-farm income is higher than marginal cost of farming.

The coefficient of household size was positive and significant at $5 \%$ for male headed household implying that the higher the household size, the higher the tendency to participate in non-farm employment by the male headed households. The coefficient of number of dependants was positive and significant at 5\% for male and female headed households respectively. This shows that the higher the number of dependants, the higher the participation decision of the household in non-farm employment. Household with higher number of mouths to feed will always look for other means of livelihood and also with the higher number of dependent all hands must not be into farming and as such same will be redeployed into other activities outside farming.

The coefficient of farm size was negative and significant at $10 \%$ for the male headed households, implying that the larger the farm size the less is the tendency to participate in non-farm activity. Households with larger farm size tend to concentrate in farming activities than households with little or no land for farming. This is in line with the finding of Bedemo et al. (2013a) who asserted that the negative impact induces them to look for off-farm activity due to push factors such as shortage of land. However, households with very small fraction of cultivated land mostly participate in selling labour outside farming activities.
The coefficient of non-labour income was negative and significant at $10 \%$ for the male headed households. This implies that households that receive non-labour income such as pension, remittances and other transfer payments tend to have less interest in non-farm activities. Besides, most of the household heads that receive non-labour income are retirees who are aged and may be less energetic to participate in other activities that may seem strenuous to them. This is consistent with the work of Idowu et al. (2013) who noted that an increase in farm income and non-labour income significantly reduced the tendency to participate in off-farm activity.

The coefficient of distance to the market was negative and significant at $10 \%$ and $5 \%$ for male and female headed households respectively. This implies that participation decision is negatively related to distance to the market. The closer the distance to the market, the higher the participation decision of the households in Non-farm employment.

\section{Hour of Work Decision}

The coefficient of age was positive and significant at $5 \%$ for male headed households and negative and significant at $1 \%$ for female headed household. By implication older male headed households spend more time in work than the female headed households. This is not unconnected to the fact that the female household heads have domestic responsibilities such as cooking and caring for their family unlike their male counterpart.

The coefficient of marital status was positive and significant at $10 \%$ for male headed households and negative and significant at $5 \%$ for female headed households. This shows that married men spend more time in work than married women. This could be as a result of the need to meet up with family responsibilities that keep the male headed households in work than their female counterpart.

The coefficient of years spent in school was positive and significant at $10 \%$ for the male and female headed households respectively. Hours of work decision is directly related to education, educated people tend to spend more time in off- farm work than they spend in their farm and their major occupation is always non farming activity unlike the uneducated ones.

The coefficient of household size was positive and significant at $5 \%$ for the male headed household but negative and significant at $10 \%$ for female headed households. The implication is that with large household size the male headed households are likely to spend more time in work so as to earn more wages to fend for the large household size. The larger the household size of the female headed household the lesser the hours of work engaged in non-farm employment. Also, the female headed households have the responsibility to take care of their children and do other domestic chores in the house than the male and as such spend less time at work. 
Table 3: Gender participation in non-farm employment (Double Hurdle Estimation Result)

\begin{tabular}{|c|c|c|c|c|c|c|c|c|}
\hline \multirow[t]{3}{*}{ Explanatory variables } & \multicolumn{4}{|c|}{$\begin{array}{l}\text { Probit regression for participation decision. } \\
\text { Dependent variable: Participation }(1 / 0)\end{array}$} & \multicolumn{4}{|c|}{$\begin{array}{l}\text { Tobit regression for hours of work decision. } \\
\text { Dependent variable: Ln (Off-farm hours worked) }\end{array}$} \\
\hline & Male & & Female & & Male & & Female & \\
\hline & Coeff & T-value & Coeff & T-value & Coeff & T-value & Coeff & T-value \\
\hline Age & .01788 & $2.80 * *$ & .05674 & $2.23 * *$ & .15943 & $2.08 * *$ & -.18278 & $-3.04 * * *$ \\
\hline Marital status & .59718 & $1.66^{*}$ & -.01479 & -0.07 & 2.6494 & $1.74 *$ & -.78679 & $-2.62 * *$ \\
\hline Years spent in school & .08863 & $2.62 * *$ & .08979 & $1.83^{*}$ & .08458 & $1.73^{*}$ & .29626 & $1.76^{*}$ \\
\hline Household size & .21823 & $2.52 * *$ & -.14177 & -1.49 & .97923 & $2.57 * *$ & -.53209 & $-1.77 *$ \\
\hline Number of dependent & .34392 & $2.04 * *$ & .06547 & $2.52 * *$ & 1.7537 & $2.40 * *$ & -.08132 & -0.38 \\
\hline Farm size & -.47023 & $-1.93 *$ & .30123 & 0.51 & -.86207 & -0.84 & -3.7367 & $-3.66 * * *$ \\
\hline Non-labour income & $-8.36 \mathrm{e}-07$ & $3.17 * * *$ & -.00001 & -0.98 & $-1.15 \mathrm{e}-06$ & -0.03 & -.02005 & $-9.79 * * *$ \\
\hline Farm income & $-1.51 \mathrm{e}-07$ & -0.19 & $-7.74 \mathrm{e}-07$ & -0.34 & $-4.46 \mathrm{e}-07$ & -1.36 & $-4.23 e-06$ & -0.56 \\
\hline Distance to the market & -.04286 & $-1.93 *$ & -.02172 & $-2.31 * *$ & -.07457 & $-1.80 *$ & -.16765 & $-1.67 *$ \\
\hline Distance to the urban centre & -.03552 & -1.57 & -.02517 & -0.64 & .24797 & $2.57 * *$ & -.19749 & $-1.86^{*}$ \\
\hline Constant & 2.0196 & $2.35 * *$ & -2.4349 & $-2.23 * *$ & 6.5122 & $1.76^{*}$ & -3.9852 & $-1.66^{*}$ \\
\hline Log Likelihood & -98.237 & & -131.781 & & -198.425 & & -160.268 & \\
\hline Pseudo $\mathrm{R}^{2}$ & 0.1034 & & 0.0949 & & 0.0338 & & 0.0276 & \\
\hline
\end{tabular}

The coefficient of number of dependants was positive and significant at $5 \%$ for the male headed household. This implies that male headed household with large number of dependants tend to spend more time in work in order to meet up with their needs. The coefficient of farm size was negative and significant at $1 \%$ for female headed household. This shows that female headed households with large farm size spend more time in their farm than they spend in other activities outside farming.

The coefficient of non-labour income was negative and significant at $1 \%$ for the female headed households implying that the higher the non-labour income the less the hours of work engaged in nonfarm employment. Female headed households with large non-labour income tend to relax and enjoy rather than engage their time in non-farm activities. This is in line with Bedemo et al. (2013b) that the estimated farm income and non-labour income significantly reduces off-farm hours of work decision for both sexes, which may be due to the substitution and income effects. This is because farm income increases the shadow value of farm labour and makes farmers devote more time on farm work. An increase in farm income may also increase the demand for leisure thereby reducing the time allocated to working off-the farm.

The coefficient of distance to the market was negative and significant at $10 \%$ for male and female headed household respectively. This is in line with apriori expectation that the higher the distance to the market the lesser the hours of work that will be put into non-farm employment like trading, handcrafting, etc. The coefficient of distance to the urban centre was positive and significant at $5 \%$ for the male headed household and negatively significant at $10 \%$ for the female headed households. The positive relationship of male headed household's distance to the urban centre with hours of work decision could be as a result of the fact that they travel to reside within their place of work during the work days and return during weekends thereby giving more time to their work; also the negative relationship between the distance to the urban centre and hours of work decision of female headed household could be as a result of the fact that the female needs to give more attention to domestic chores and children upbringing and as such spend little time at her place of work that is far from her resident.

\section{CONCLUSIONS/RECOMMENDATIONS}

This study focused on gender participation in nonfarm employment and the employment type of the farmers in the area. The female headed households were found to receive more non-labour income that the male headed household and also the male headed households were found to spend more time at work than the female headed housed in the study area.

Among the non-farm employment activities, non-farm unskilled labour was dominated by females while self-employment activities were dominated by males. Generally fishing, forest related activities, non-farm skilled labour experienced low participation.

From the estimated result of the double hurdle, age, marital status, years spent in school, household size, number of dependent, farm size, non-labour income and distance to the market significantly influenced the participation decision of farmers in non-farm employment in the study area while age, marital status, years spent in school, household size, number of dependent, farm size, non-labour income, distance to the market and distance to the urban centre significantly influenced the hours of work decision of the farmers in the study area.

Policy measures that will improve the skills and the educational level of the farmers especially the female will go a long way to reducing number of unskilled labours while increasing on the number of skilled labour of the people in the study area.

The benefits of women's participation in nonfarm employment are determined by their control of productive resources and household level decisions. Concerted effort must, therefore, be made to ensure that women have better, cheaper and equal access to land so as to improve their use of land for agricultural purposes since they spend less time in non-farm activities. 


\section{REFERENCES}

Abebe D. (2002). Farm Households Labour Supply to OffFarm Activities in Ethiopia. MSc Thesis Submitted to the School of Graduate Studies, Addis Ababa University, Addis Ababa, p. 79

Ahmadu J. and Idisi P.O. (2014). Gendered participation in cassava value chain in Nigeria. Journal of Agricultural Science and Soil Science, 2 (11), 147-153

Bedemo A., Getnet K., Kassa B. and Chaurasia S.P.R. (2013a). Off-farm labour supply decision of adults in rural Ethiopia: Double hurdle approach. Journal of Agricultural Economics and Development, 2 (4), 154-165

Bedemo A., Getnet K. and Kassa B. (2013b). Determinants of labour market participation choice of farm households in rural Ethiopia: multinomial logit analysis. Journal of Economics and Sustainable Development, 4 (1), 133-141

Beyene A. (2008). Determinants of off-farm participation decision of farm households in Ethiopia. Agrekon, 47 (1), 140-161

Blaylock J. and Blisard W. (1992). U.S. cigarette consumption: the case of low income women. American Journal of Agricultural Economics, 74 (3), 668-705

Costa R. and Bob R. (2012). Gender and rural non-farm entrepreneurship. World Development Report, Washington, DC

Cragg J. (1971). Some statistical models for limited dependent variables with applications to the demand for durable goods. Econometrica, 39 (2), 829-844

Csaki C. and Lerman Z. (2000). Agricultural Transition Revisited: Issues of Land Reform and Farm Restructuring in East Central Europe and the Former USSR. Washington DC: World Bank

Davis J. and Bezemer D. (2004). The development of the rural non-farm economy in developing countries and transition economies: key emerging and conceptual issues. Chatham, UK: Natural Resources Institute

Getachew L., Augustine S.L., Mwangi W., Moti J. and Roberto L. (2009). Household resource endowment and determinants of adoption of drought tolerant maize varieties: double-hurdle approach. Contributed Paper Prepared for Presentation at the International Association of Agricultural Economists Conference, Beijing, China, 16-22 August, 2009

Idowu A.O., Ojiako I.A. and Omotoyole I.A. (2013). Participation and wage of rural female headed households in Nigeria non-farm employment. European Scientific Journal, 9 (13), 194-219

Ike P.C. (2015). Determinants of participation in non-farm economic activities in South East Nigeria: a tobit analysis approach. Journal of Biology, Agriculture and Healthcare, 5 (2), 102-108

Matshe I. and Young T. (2004). Off-farm Labour Allocation Decisions in Small-Scale Rural Households in Zimbabwe. Agricultural Economics, 30, 175-186

McCarthy N. and Sun Y. (2009). Participation by men and women in off-farm activities: an empirical analysis in rural Northern Ghana. Paper Presented at the International Association of Agricultural Economists Conference, Beijing, China, 16-22 August, 2009
Nicodemo C. and Waldmann R. (2009). Child-care and participation in the labor market for married women in mediterranean countries. IZA Discussion Paper No. 3983 January 2009

Norsida M. and Ismaila S. (2009). Off-farm employment participation among paddy farmers in the Muda Agricultural Development Authority and Kemasin Semerak granary areas of Malaysia. Asia-Pacific Development Journal, 16 (2), 41-153

NPC (2006). Nigerian Census Figures. Nigerian Population Commission (NPC), Abuja, Nigeria

Olukemi L. (2009). Female Labour Force Participation in Nigeria, Determinants and Trends. Lagos: University of Lagos Press

Oluwatayo I.B. (2009). Poverty and income diversification among households in rural Nigeria: A gender analysis of livelihood patterns. Conference Paper No.41@ The 2nd Instituto de Estudos Sociais e Económicos (IESE) Conference on 'Dynamics of Poverty and Patterns of Economic Accumulation in Mozambique', April 22-23, 2009

Onya C.S., Okezie A.C. and Ejiba I.V. (2016). Determinants of participation in non-farm employment among rural farmers in Ebonyi State, Nigeria. Journal of Scientific Research and Reports, 11 (6), 1-11

Onya S.C., Okezie C.A. and Ejiba I.V. (2019). Double hurdle modelling approach to local rice consumption in Ikwuano Local Government Area of Abia State, Nigeria. Agro-Science, 18 (2), 20-25

Pagan A. and Vella P. (1989). Diagnostic tests for models based on individual data: A survey. Journal of Applied Econometrics, 4 (Supplement), S29-S59

Quisumbing A.R. (2003). Household Decisions, Gender, and Development. A Synthesis of Recent Research. International Food Policy Research Institute, Washington, DC

Roslan A. and Siti H (2011) Does farmer's diversification into non-farm employment reduce their likelihood of poverty? Evidence from Malaysia. Journal of Business and Political Research, 6 (1), 145-155

Simtowe F. (2010). Livelihoods diversification and gender in Malawi. African Journal of Agricultural Research, 5 (3), 204-216

Simtowe F. and Zeller M. (2007). The impact of access to credit on the adoption of hybrid maize in Malawi: an empirical test of an agricultural household model under credit market failure. AAAE Conference Proceedings, 131-145

Tassew W. (2000). Economic Analysis and Policy Implications of Farm and Off-Farm Employment: A Case Study in the Tigray Region of Northern Ethiopia. $\mathrm{PhD}$ Thesis Submitted to Wageningen University, Wageningen, $293 \mathrm{pp}$.

Wooldridge J. (2002). Econometric Analysis of Cross Section and Panel Data. The MIT Press, Cambridge

Zhang L.A., De Brauw and Rozelle S. (2003). Labour market liberalization, employment and gender in rural China. In: Proceedings of the 25th International Conference of Agricultural Economists (IAAE), Durban 